\author{
Pawel Wontorski \\ dr inż. \\ Politechnika Warszawska \\ Wydział Transportu \\ Zakład Sterowania Ruchem i Infrastruktury Transportu \\ Rail-Mil Computers sp. z o.o. sp. k. \\ pawel.wontorski.dokt@pw.edu.pl
}

\title{
The concept of an integrated rail transit system based on tram-trains in the metropolitan area on the example of Piaseczno
}

\begin{abstract}
The article presents the concept of an integrated rail transit system for Piaseczno, which is one of the main urban centers of the Warsaw Metropolitan Area. The conditions for the development of new lines and the use of existing infrastructure were analyzed. An agglomeration rail transit system based on normal and narrow gauge railways and tram-train was proposed, taking into account the stages of network development and integration of various modes of transport. The proposed solution can be a model for the development of rail transport in the metropolitan area.
\end{abstract}

Keywords: Tram-train; Narrow-gauge railway; Piaseczno

\section{Introduction}

The railway reached Piaseczno in the 1890s. However, it was not a standard-gauge railway, but a narrow-gauge access railway: Wilanowska and then Grójecka [16]. The route of the Grójecka Railway started at Unii Lubelskiej Square and is led on the left side of the Nowa Aleksandryjska Road (today's Puławska Street). In 1924 it reached Nowe Miasto on the Pilica via Tarczyn, Grójec, and Mogielnica. In 1935, both railways were joined and the track spacing was standardized to $1000 \mathrm{~mm}$. In 1937, the starting station was moved to Szopy Polskie (hence the name of the Szopy station, temporarily known as the South Railway Station), in the area of the current Wilanowska station of the Warsaw Metro. [3].

For many years, trains ran to Piaseczno along today's Puławska Street, constituting an important factor in the development of suburban settlements such as: Grabów, Pyry, Dąbrówka, Mysiadło, and Iwiczna. The city of Piaseczno and the settlements along the narrow-gauge railway route on the Piaseczno - Tarczyn section (Zalesie, Gołków, Głosków, Złotokłos were also developing).

In 1934, a new standard-gauge railway line from Warsaw to Radom (currently line No. 8) was built through Piaseczno. Its route was marked west of the Szopy - Piaseczno narrowgauge railway line. Due to the fact that Piaseczno had developed buildings, the new line had to be led outside the city.

The development of the automotive industry in the post-war period gradually led to the suspension of regular passenger and freight transport on access railways near Warsaw, including the Grójecka Access Railway. The standard gauge railway took over most of the transport on the route Warsaw - Piaseczno and further south.

The narrow-gauge railway infrastructure in the area of Warsaw was liquidated. To this day, only the tracks on the Piaseczno - Nowe Miasto nad Pilica section have survived, while the Piaseczno - Tarczyn section, served by the Piaseczyńsko-Grójeckie Narrow Gauge Railway Society, is passable. The transports are of a tourist nature. Regular passenger traffic has not been operated since 1991. Since 2004, the railway has been operating under the name Piaseczyńska Kolej Narrow-Gauge Railway [30]. 
In 1983, the trolleybus line No. 51 was launched on the route: South Railway Station Piaseczno along Puławska Street. The line was suspended in 1995 and was replaced by the bus line No. 709. In 2000, the trolleybus line was finally removed. The standard-gauge railway and bus lines remained to service Piaseczno.

\section{Analysis of the conditions for the development of rail transport in Piaseczno}

The modern rail transport system serving Piaseczno and the Piaseczno county is based on the railway line No. 8, with the station located relatively far away from the city center. The distance from the Piaseczno railway station to the central Piłsudski Square is almost $1.5 \mathrm{~km}$ along the main streets [31]. Most of the multi-family buildings are also far from the station.

Therefore, the settlement structure and transport system of Piaseczno cannot be compared with cities such as Piastów, Pruszków, Legionowo, Brwinów, or Ząbki. These centers developed intensively after the construction of standard-gauge railways, approximately concentrically around the station. The communication accessibility by rail transport of the center of Piaseczno is insufficient and worse than the above-mentioned centers.

The consequence of the peripheral location of the railway station in Piaseczno is an unusually high number of passengers using suburban bus lines to and from Warsaw, compared to other cities in the Warsaw agglomeration. The transport is organized by the Public Transport Authority in Warsaw (ZTM). During the morning rush hour, the cordon of Warsaw exceeds approximately 1,200 passengers of suburban bus transport in the corridor of Puławska Street towards Warsaw and approximately 500 passengers towards Piaseczno. This puts Puławska Street in the first place in terms of the size of passenger flows by buses among all exit routes in the entire Warsaw agglomeration, [25].

The most important bus line connecting Piaseczno with Warsaw is line no. 709, served by large-capacity buses that run at the peak frequency even below 4 minutes, and off-peak every 10 minutes. It is also the ZTM suburban (zone) line in the entire Warsaw Metropolitan Area with the highest load in terms of the number of passengers transported [42].

It should be emphasized that the number of passengers traveling from Piaseczno towards Warsaw, from crossing the capital's border to the intersection of Puławska with Poleczki Streets is slowly growing from 1,200 to 1,800 passengers. Only from the abovementioned intersection, the number exceeds 2,200-2300 passengers (Figure 1). The proportions in the distribution of passenger flows have been maintained for many years, which was already confirmed by the research from 2005 [1]. Such a distribution means that Piaseczno itself and its immediate vicinity are by far the dominant traffic generator in this direction. However, in the section of Puławska Street from Piaseczno to the intersection with Poleczki Street in Warsaw, there are no significant destinations and sources of travel, which, when considered independently of Piaseczno, justify the construction of rail transport infrastructure [1]. 

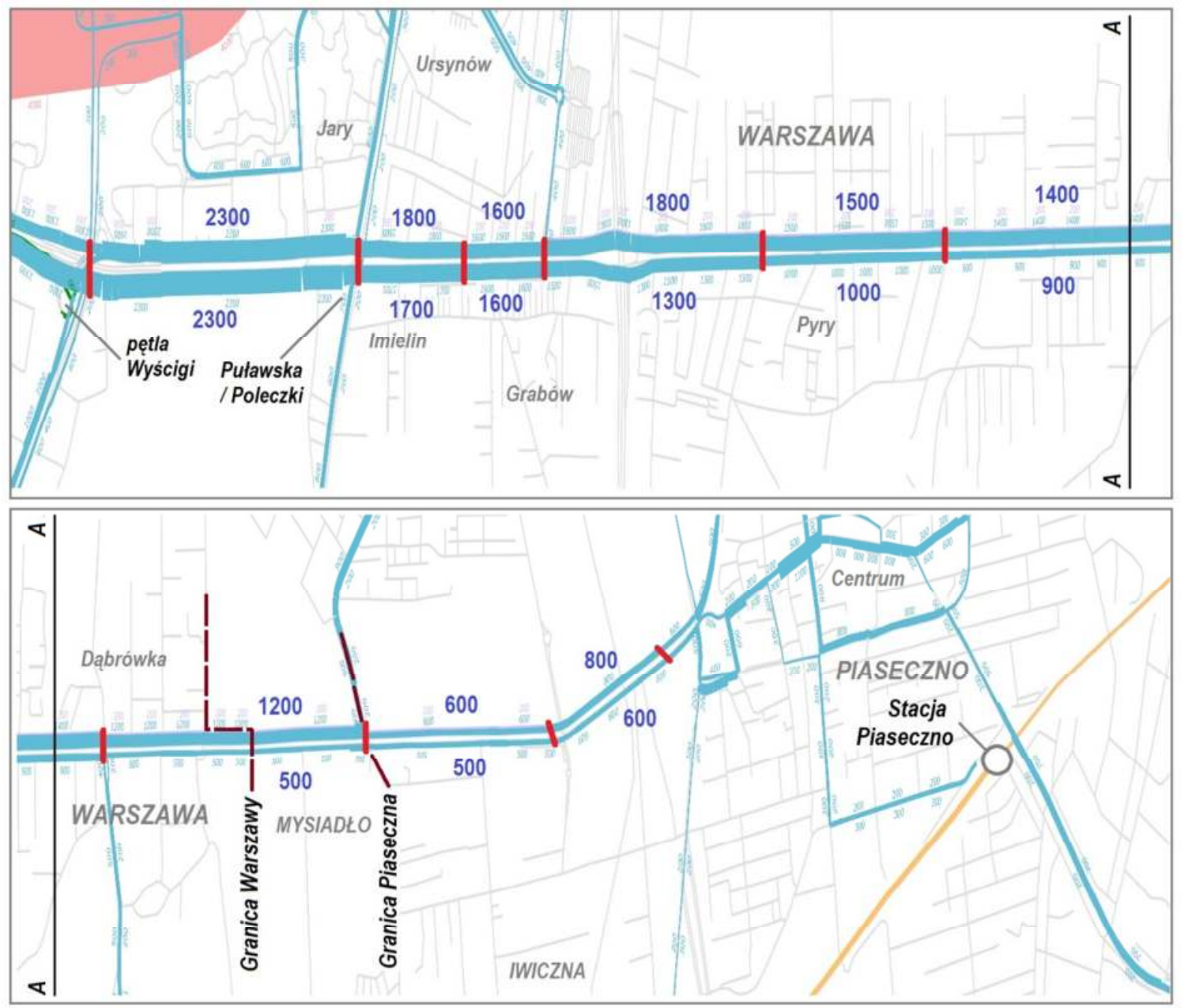

1. Passenger flows in public transport in the corridor of Puławska Street in the morning rush in 2015. Source: own study based on [25]

The number of passengers arriving by rail (line 8) to the Piaseczno station from the south (from the direction of Radom) does not exceed 400. From the Piaseczno station, the number of passengers traveling towards Warsaw increases to 700. The number of passengers crossing the Warsaw cordon in Nowa Iwiczna (between Piaseczno and Warsaw) is already around 800, and according to forecasts for 2050 this number will almost double [25].

The intensity of individual traffic during the measurement period on the cordon of Warsaw at the measurement point at ul. Puławska (national road no. 79) amounted to 58,063 vehicles within 16 hours of measurement [25]. It was the fifth-highest result among 55 measuring points marked on the cordon of the capital but at the same time the second-highest among national and provincial roads that are not a motorway or expressway (in this category, more vehicles traveled only on road No. 719 along Jerozolimskie Avenue).

Apart from the main direction of travel from Piaseczno to Warsaw and vice versa, there are also several secondary directions [25]. These are mainly two corridors leading south from Piaseczno:

- Armii Krajowej Street and its extension along national road No. 79 towards Góra Kalwaria (along the narrow-gauge railway route no longer existing [16]),

- Sienkiewicza Street and its extension through Zalesie Dolne and Gołków towards Tarczyn (along the route of the Piaseczyńska Narrow-Gauge Railway) - it is also mainline of buildings in the Piaseczno commune outside the city itself. 
The directions to Magdalenka and Konstancin-Jeziorna are of less importance.

The northern part of the city is crossed from west to east by the standard-gauge railway line No. 937 leading from the Warszawa Okęcie station (railway line No. 8) to Konstancin-Jeziorna and then as a siding to the "Siekierki" Heat and Power Plant. The line is currently not used for passenger transport.

The city and commune of Piaseczno are characterized by dynamic urbanization. Over the last 20 years, over 20,000 new residents [33] have come to Piaseczno, which is over 85\% increase. Among the cities of the Warsaw agglomeration, only Ząbki and Marki recorded a greater increase in terms of percentage, but Piaseczno was the place where the newest inhabitants came in absolute numbers (apart from Warsaw). In 1997, Piaseczno was the seventh city of the agglomeration (excluding Warsaw), of a similar size to Grodzisk Mazowiecki. In 2018, it moved to the third position (Legionowo and Pruszków are larger).

Only in 2018, 497 new apartments were commissioned in Piaseczno, which puts the city in the absolute top of the cities of the Mazowieckie voivodship [33]. At the same time, 620 apartments were completed in the rural part of the Piaseczno commune. This gives a total of 1,117 apartments, which is more than, for example, in the entire Pruszków district. New jobs, industrial and service facilities are also being created in the city and its vicinity.

\section{Analysis of rail transport development plans for Piaseczno}

In the strategic and planning documents prepared over the last few years for the city and commune of Piaseczno (and in documents at the regional level), statements about the need to strengthen the role of rail transport in communication services for this part of the Warsaw agglomeration are repeated.

Table 1 lists the basic investments in rail transport in the city and commune of Piaseczno, postulated for implementation in planning documents. Figure $\mathbf{2}$ shows a synthesis of the most important planned investments. 
Tab. 1. List of the most important investments in rail transport in the area of the city and commune of Piaseczno postulated for implementation in planning documents.

\begin{tabular}{|c|c|c|c|c|c|c|c|c|c|c|}
\hline No. & Planned investment & 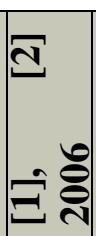 & 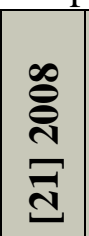 & 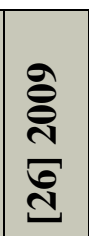 & 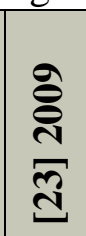 & 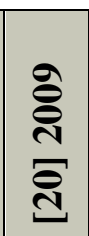 & 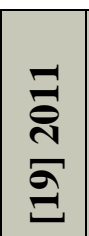 & 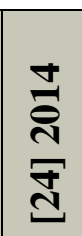 & 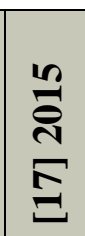 & 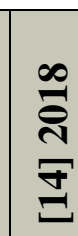 \\
\hline 1 & 2 & 3 & 4 & 5 & 6 & 7 & 8 & 9 & 10 & 11 \\
\hline 1. & modernization of the railway line No. 8 & yes & yes & yes & yes & yes & yes & yes & yes & yes \\
\hline 2. & $\begin{array}{l}\text { development of connections on line No. } \\
8 \text { (SKM) }\end{array}$ & - & yes & yes & yes & - & yes & yes & yes & - \\
\hline 3. & extension of line No. 8 to four tracks & - & - & & - & - & - & - & - & yes \\
\hline 4. & $\begin{array}{l}\text { construction of new stops on the line No. } \\
8\end{array}$ & - & yes & yes & - & - & - & yes & - & - \\
\hline 5 . & $\begin{array}{l}\text { adaptation of the railway line No. } 937 \\
\text { for the needs of regular passenger } \\
\text { transport }\end{array}$ & - & yes & yes & yes & yes & - & yes & yes & yes \\
\hline 6. & $\begin{array}{l}\text { adaptation of the infrastructure of the } \\
\text { Piaseczyńska Narrow-Gauge Railway to } \\
\text { the needs of regular passenger transport }\end{array}$ & - & - & yes & yes & yes & - & yes & yes & yes \\
\hline 7. & $\begin{array}{l}\text { integration of the railway station PKP } \\
\text { Piaseczno }\end{array}$ & - & - & yes & yes & yes & - & yes & yes & yes \\
\hline 8. & $\begin{array}{l}\text { with the Narrow Gauge Railway of } \\
\text { Piaseczno }\end{array}$ & - & op. & - & - & - & - & - & - & - \\
\hline 9. & tram route along Puławska Street & yes & - & & op. & yes & - & op. & yes & - \\
\hline 10. & bus lane along Puławska Street & op. & yes & - & - & - & - & op. & - & - \\
\hline 11. & trolleybuses along Puławska Street & op. & - & - & - & - & - & - & - & - \\
\hline
\end{tabular}

op. - investment considered as optional 


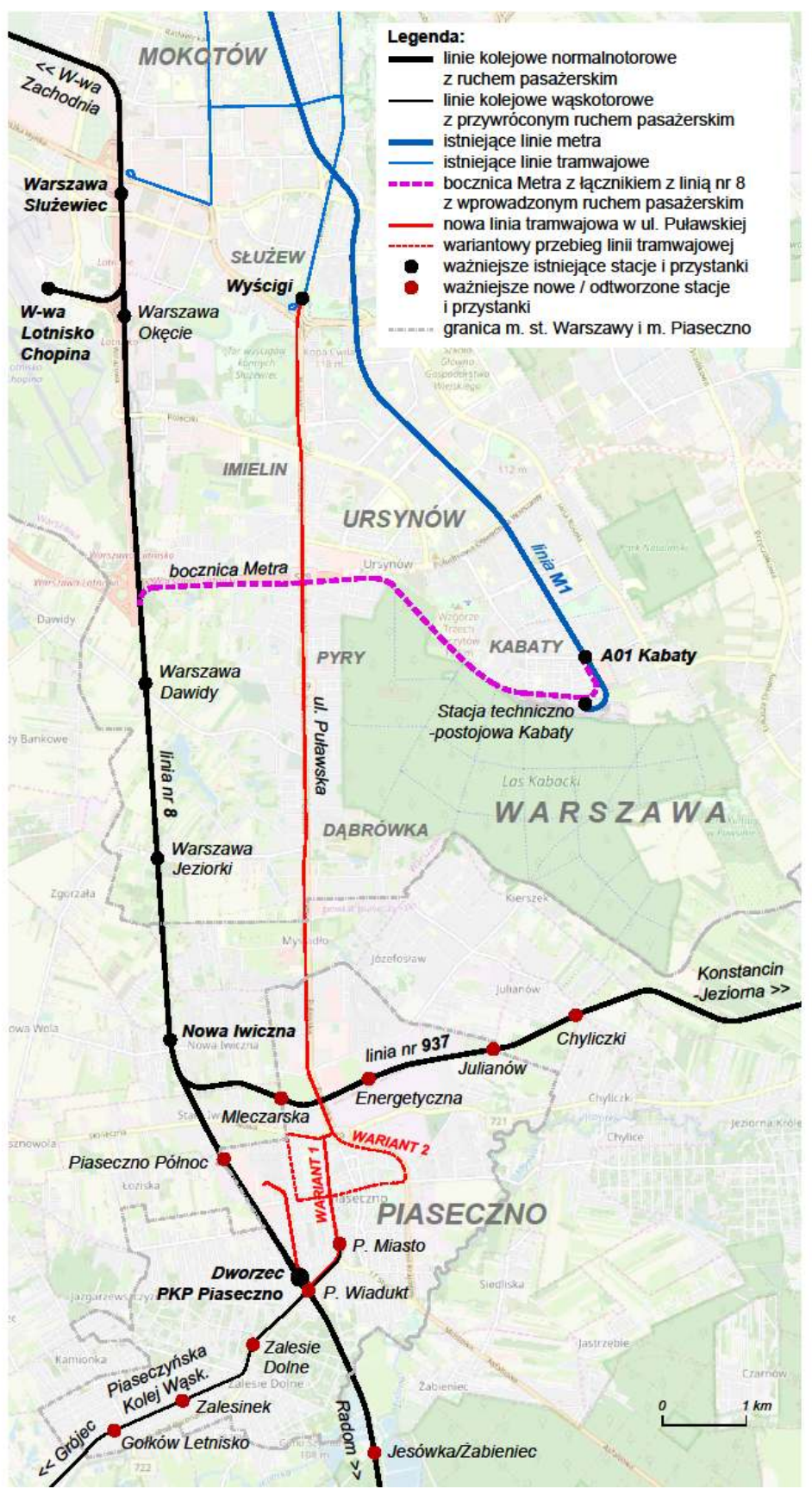

2. Synthesis of investments in rail transport postulated for implementation in planning documents. Source: own study based on: [1], [2], [14], [17], [19], [20], [21], [23], [24], [26] in reference to: [31]

The necessity to modernize the railway line No. 8 , along with the construction of new stops, is indicated in practically all key planning documents, including: [14], [19], [21], [24]. It is planned to adapt the line to the needs of Szybka Kolej Miejska (SKM) along with the construction of new stops and parking lots "P\&R". The Spatial Development Plan for the Mazowieckie Voivodeship [14] also includes a provision on the prospective reconstruction of line No. 8 on the agglomeration section (e.g. Czachówek Płd. Station) to four tracks. It is worth noting that SKM in Warsaw plans to launch a new line to Piaseczno in 2023 [41], routed by the Warszawa Zachodnia station to the Warszawa Gdańska station, which will be possible after the completion of the modernization of the former [18].

Most documents ([14], [21], [23], [24], [26]) plan to adapt the railway line No. 937 (Siding to EC "Siekierki") to meet the needs of regular passenger transport to Konstancin- 
Jeziorna (and even further [26]) along with the construction of several passenger stops. The new line would run light railbuses, connected in Nowa Iwiczna with SKM and regional trains on line No. 8.

Opinions are divided regarding the restoration of passenger traffic on the Piaseczyńska Narrow Gauge Railway. Document [21] includes a narrow-gauge railway at the stage of analysis, but in the proposed directions of transport development, it was not finally recommended to recreate regular passenger services on it. However, in [24] it is postulated to recreate the Grójecka Access Railway [currently Piaseczyńska Narrow-Gauge Railway] with modernization to support local passenger traffic and tourist traffic, along with the revitalization of the station and the construction of parking lots in the vicinity of all stations. An important element of this project would be a transfer junction integrating the normal and narrow-gauge railway in the area of the Piaseczno PKP/Piaseczno Viaduct station.

In the current Spatial Development Plan for the Mazowieckie Voivodeship of 2018 [14], it is proposed to use the narrow-gauge line Piaseczno - Grójec as a regional tram with the introduction of a line to the Grojec downtown and the adaptation of the network of stops. Similar proposals were included in [26] and [17], bearing in mind the distance of the narrowgauge railway from the centers of Tarczyn and Grójec (and Piaseczno). In [20] it was also proposed, in relation to narrow-gauge railways in general, the possibility of building a third rail in order to introduce standard-gauge rolling stock on the route..

In subsequent studies, the idea of a tram line along Puławska Street was repeated. In 2006, documents [1] and [2] were prepared, being a detailed study of the planned tram route from Warsaw to Piaseczno along Puławska Street. At the same time, the document stated that the main task of the new route should be to quickly transport passengers from Piaseczno and the surrounding area to the Poleczki/Pileckiego intersection and to the Wilanowska Metro station [1], due to a slight increase in the number of passengers on the route between Piaseczno and Warsaw, about which was written before. This statement is crucial from the point of view of the legitimacy of choosing the route for the tram in Puławska Street, which is not the only possible corridor for its passage.

In [2] the concept of the route location, the location of stops, street sections, possible collisions, and proposals for their solutions, as well as communication services for the Piaseczno city center in two variants are presented in detail.

The provision about the fast tram as an "acceptable solution" appeared in the Study of conditions and directions of the spatial development of the city and commune of Piaseczno in 2009 [23]. In the Study of 2014 [24], apart from the fast tram option, an additional bus lane was replaced along Puławska Street.

The 2008 study of the communication system of the Piaseczno Commune [21] turned out to be very conservative in terms of improving public transport between Piaseczno and Warsaw along Puławska Street. It was proposed, inter alia, introducing a fast bus line running on Puławska Street on a separate lane or road. The authors argued this with significantly lower construction costs compared to the tram route and slightly lower transport capacity with a comparable travel time.

It should be emphasized that the tram route to Piaseczno is not included in the basic planning documents of the capital city of Warsaw: [22], [15]. and [40] It appeared in the report from 2014 [32] among the lines recommended for construction, but only in the last place (after 2040).

A separate issue is the connection of Piaseczno with the Warsaw Metro. In [21] it was proposed, for example, to use the existing Metro siding by building a short railway link, providing access from Piaseczno to the Kabaty metro station. The idea of extending the M1 metro line directly to Piaseczno, although it appeared in some pre-election spots, was not supported by any planning and strategic documents due to the very high costs, 
disproportionate to the effects, the need to run a tunnel under the undeveloped area of Kabacki Forest and difficulties in financing such a large project by the city and commune of Piaseczno [34].

None of the documents propose to run the tram route along a different corridor than along Puławska Street, including the double-system tram.

\section{The concept of a two-system tram in the transport service of Piaseczno}

The following conclusions were drawn from the conducted analyzes, constituting assumptions for the concept of the rail transport system in the Piaseczno communication service:

- the basic rail transport system should be based on the railway line No. 8, which has been modernized on the Warszawa - Piaseczno section, and will then be expanded to a four-track line [39],

- the main transfer junction should be built at the railway station of the Piaseczno PKP station and provide the shortest possible pedestrian paths between different means of transport,

- the accessibility of the railway line No. 8 should be improved by connecting the Piaseczno railway station with the city center, moreover, new passenger stops, delivery lines, "P\&R" car parks, easier transfers,

- passenger transport should be launched on the railway line No. 937 along with new passenger stops,

- regular passenger transport on the narrow-gauge railway line should be restored (the line requires modernization and integration with the Piaseczno railway station),

- a tram line from Piaseczno to Warsaw should be launched, with the city of Piaseczno being a traffic generator sufficient to launch a tram connection with Warsaw, and an increase in passenger flows along Puławska Street between Piaseczno and Warsaw is relatively small.

In the first stage of the development of the rail transport system in Piaseczno, it is proposed to introduce double-system trams, running between Piaseczno and Warsaw, bypassing Puławska Street. Between the cities, the vehicles would travel on the suburban tracks of the railway line No. 8 (in the future it would be expanded to four tracks: two longdistance and two suburbans). However, in the area of Warsaw and Piaseczno, they would run down to tram tracks running along city streets.

The proposed rail transport system based on a double-system tram is shown in Figure 3. The main axis of this system is visible: railway line No. 8 and the final sections of the tram route:

- north in the area of Warsaw integrated with the existing tram line along Marynarska Street (currently terminated by a PKP Służewiec terminus next to the Warszawa Służewiec railway station),

- southern in the area of the city and commune of Piaseczno, run from the area of the Nowa Iwiczna passenger stop, initially by line No. 937, and then as a completely new tram route through the center of Piaseczno (for example along Puławska - Kościuszki Sienkiewicza Streets to the Piaseczno railway station).

The tram would start its course, for example, from the Wierzbno Metro stop, where it would be integrated with the M1 line of the Warsaw Metro, and then it would move along Wołoska and Marynarska Streets while providing communication services to the office district in Służewiec. In the worst case, the starting stop would be PKP Służewiec (even without connection to the tram system in Warsaw). In the last solution, however, one cannot speak of the full use of the advantage of a double-system tram over other means of public transport, which results from limiting the number of changes to a minimum. 


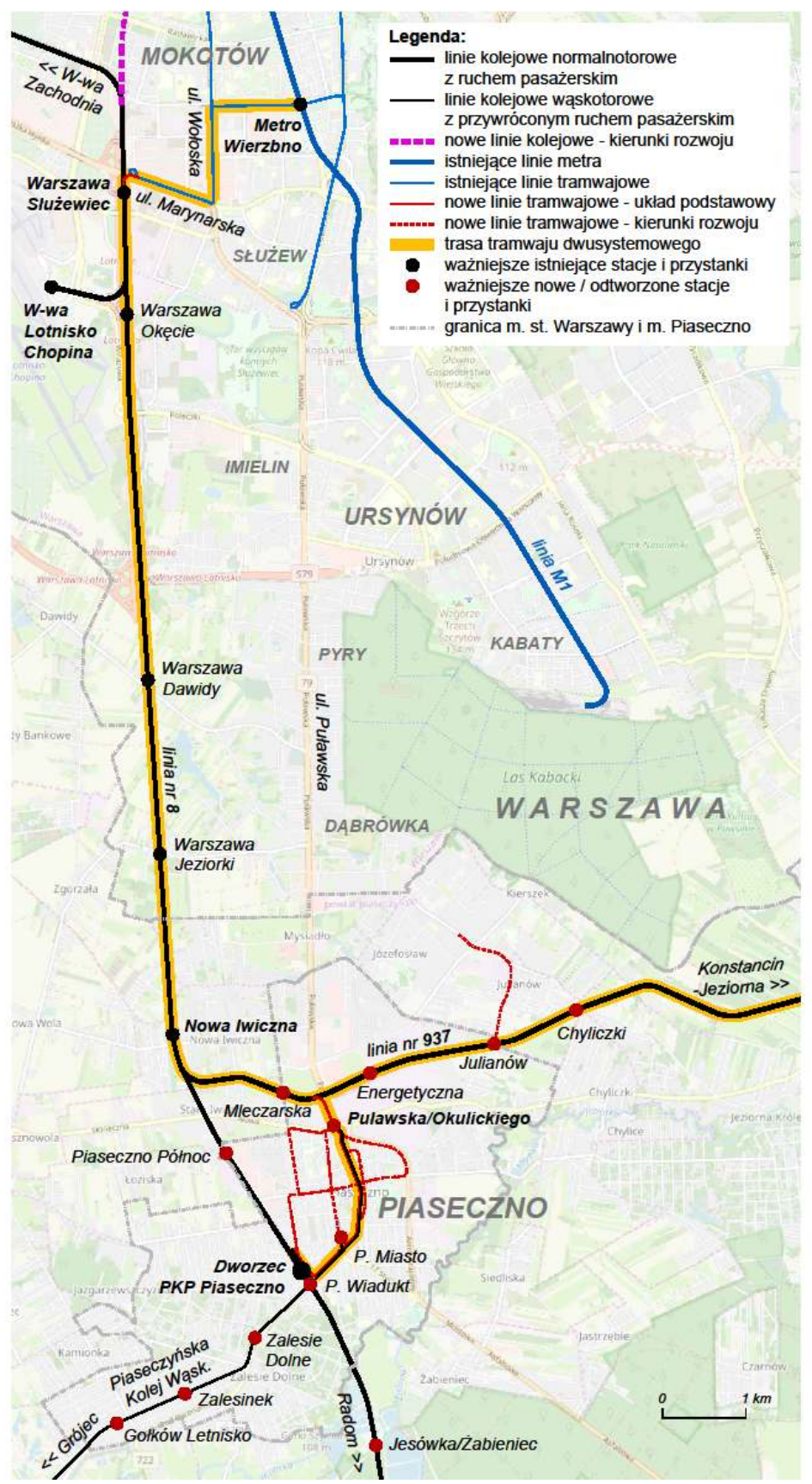

3. The proposed rail transport system in the Piaseczno communication service. Source: own study in reference to: [31]

Then the tram would run over a short lane onto the tracks of the railway line No. 8. The tram line would be included in the railway network within the Warszawa Okęcie station. The connection in a collision-free manner would be extremely difficult in this place due to the immediate vicinity of the Marynarska road junction. Therefore, in the first stage, it would be implemented in one level (perhaps only in the area of junctions No. 22 and 23 of the Warszawa Okęcie station [37]).

The entry of the vehicle to the station would take place on the basis of an enabling signal on the entry signal, operated from the LCS Okęcie. The rules for integrating the tram system with the railway system in the Polish regulations are presented in [27] and [4]. The tram could enter the line No. 8 earlier - near the PKP Rakowiec stop (from the tram route in Grójecka Street), but this would seriously limit the capacity of the most loaded section of the line No. 8 Warszawa Zachodnia - Warszawa Służewiec. 
It was planned to expand the railway line No. 8 to four tracks at least to Piaseczno. Ultimately, one pair of tracks can be routed through a tunnel to the center of Warsaw, bypassing Warsaw West. Double-system trams would run on suburban tracks. A detailed functional, technical, financial and economic analysis of including the tram route into line No. 8 will be the subject of a separate study.

In the vicinity of the Nowa Iwiczna stop, vehicles would exit to the railway line No. 937 (towards Konstancin-Jeziorna). Due to the limited capacity of a single track, a second track should be built on this line up to the area of the crossing over ul. Pulawska. At the Mleczarska branch station organized in this area, the trams would run down to the newly built tram route heading towards the very center of Piaseczno. The checkpoint should be included in the LCS Okęcie control area.

The tram route can be run through downtown Piaseczno in several variants, shown in Figure 4, along the streets:

- Option A: Puławska - Kościuszki - Sienkiewicza - Piaseczno Railway Station,

- Option B: Puławska - Kościuszki (towards the south)/Sierakowskiego and Warszawska (towards the north) - Sienkiewicza - Piaseczno Railway Station,

- Option C: Puławska - Wojska Polskiego - Sienkiewicza - Piaseczno Railway Station (similar to option1 from [2]),

- Option D: Puławska - Polish Army - Sienkiewicza - Piaseczno - Dworcowa Railway Station - Jana Pawła II,

- Option E: Puławska - Okulickiego - Powstańców Warszawy - Jana Pawła II Chyliczkowska - Armii Krajowej - Puławska (similar to variant 2 from [2]).

Options A and B intersect the strict center understood as Piłsudski Square. Such routing significantly increases the accessibility of the tram, integrates it with the pedestrian zone, contributes to changing the image and revitalizing the urban space, but requires serious changes in the organization of traffic in the central part of the city. Options C and D are easier to implement, they pass through large housing estates, but are run outside the strict center. Option E covers the largest housing estates in Piaseczno in a loop system, but in the author's opinion it should be rejected due to the lack of integration with the railway station of the Piaseczno railway station. 


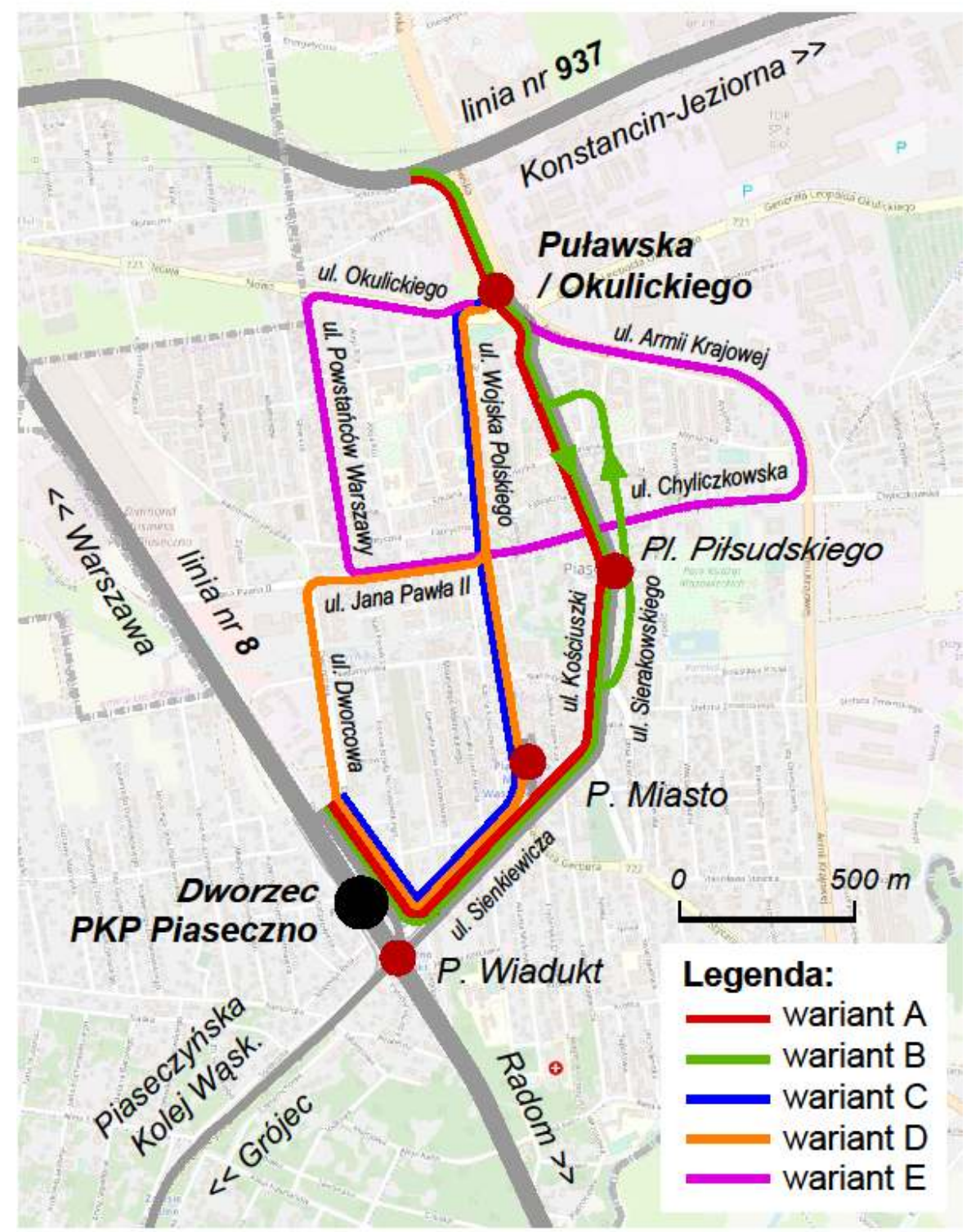

4. Basic variants of the tram route passing through downtown Piaseczno. Source: own study in reference to: [31]

The tram route will run mostly next to the road or along the section dividing the road (along dual carriageways). Only in the center should consider laying rails in the road and running trams together with vehicle traffic. On Sienkiewicza Street, the tram route may coincide with the initial section of the Piaseczyńska Narrow-Gauge Railway (one of the tracks can be equipped with a third rail).

Initially, options A and B are recommended. The final selection should be made on the basis of a more detailed functional and technical study as well as financial and economic analysis..

\section{Movement issues and the effects of introducing a double-system tram}

The presented concept of transport services in Piaseczno is based on the Karlsruhe model [8], [9] and very much resembles, for example, the method of transport services in the city of Heilbronn with a population of over 100,000. The double-system trams in the city of 
Karlsruhe run on the city's tram network. At the city border, the vehicle joins the railway to Heilbronn, which is $70 \mathrm{~km}$ away, and moves on the basis of a railway signal. After reaching the main train station in Heilbronn, the vehicle re-enters the city tram system.

The distance between the center of Piaseczno and the Służewiec train stop is less than $14 \mathrm{~km}$. The length of the rail section of the double-system tram would be approximately 13 $\mathrm{km}$. The tram section built from scratch, running through Piaseczno along Puławska Kościuszki - Sienkiewicza streets to the Piaseczno railway station, would be $3 \mathrm{~km}$ long. This includes the second track of line 937 on a $1.5 \mathrm{~km}$ section, which can be built independently for passenger connections to Konstancin-Jeziorna, and the electrification of this section with $600 \mathrm{~V}$ DC ("tram").

For comparison, the tram route planned in [1] and [2], starting from the Wyścigi terminus in Warsaw to its end at the Piaseczno railway station, would be over $13 \mathrm{~km}$ long. A two-system tram allows to achieve a similar end result by reducing the length of the railroad built from scratch by three or four times compared to the tram route in the corridor of Puławska Street.

The tram will overcome the route from the Warszawa Służewiec stop to the Nowa Iwiczna stop in about 10-12 minutes (according to the current timetable for electric units [36]). Drive along a parallel route at Puławska Street would be about twice as long [1]. As part of the modernization of the railway line No. 8, a four-joint automatic line block (sbl) [38] was installed, which allows vehicles with various traction parameters and braking distances to be driven [29]. The next two lanes would probably also receive a four-leg automatic line lock.

It is planned to maintain the frequency of trams running every 5-10 minutes during peak times and every 10-15 minutes off-peak and on holidays. The frequency was determined based on the current timetable of the bus line No. 709 and other suburban lines [42]. Meanwhile, the capacity of a pair of suburban tracks equipped with a four-way automatic line lock is estimated at 24 trains/h in each direction (sequence time 2.5 minutes) [6]. Dual-system vehicles should fit into the timetable with SKM and regional trains, the more so as they will take over a significant part of passengers of these railways.

A separate issue is the organization of the traffic of double-system vehicles and the arrangement of timetables so as to maintain regularity of traffic regardless of delays caused by congestion in urban sections of the system. This problem was also analyzed in Polish publications [5], [13], [29].

The first stage of the development of the system involves the integration of doublesystem trams with bus lines transporting passengers to the main interchange nodes: the Piaseczno railway station and the Puławska/Okulickiego intersection. At the same time, the number of suburban buses running along Puławska (mainly 709) should be reduced and adapted to the needs of the corridor service on Puławska Street.

\section{Further development of the rail transport system in the Piaseczno region}

Further development of the transport system will depend on the investment opportunities of local authorities and the increase in demand for passenger transport.

The most important directions for the further development of the system are presented below, in the order considered by the author as the most reasonable and probable, also confirmed in the strategic documents of the city and commune of Piaseczno. The directions of the system development are shown in the Figure 3.

1. Adaptation of the railway line No. 937 to the needs of passenger transport, at least on the section Nowa Iwiczna - Piaseczno - Julianów - Konstancin-Jeziorna, along with the construction of passenger stops with $\mathrm{P}+\mathrm{R}$ car parks. In the first stage, the line will be run by light diesel railbuses, ending at the Nowa Iwiczna stop, connected with trains and double-system trams going on by line No. 8 to Warsaw. In the second stage, the line can 
be fully electrified with $600 \mathrm{~V}$ DC and double-system trams can be introduced. Then extend their connection to Warsaw-Mokotów on the one hand, so that a change in Nowa Iwiczna is not necessary, and on the other to the center of Konstancin-Jeziorna by building a short tram section.

2. Restoration of regular, daily passenger transport on the Piaseczyńska Narrow-Gauge Railway, along with the revitalization of the infrastructure and the purchase of light, diesel-powered tram rolling stock. The main route should be the Piaseczno - Tarczyn section with the construction of a short branch to the center of Tarczyn. Ultimately, trains should run to Grójec, also after connecting a branch to the city center, which would significantly increase the accessibility of this means of transport [17]. In the first stage, trains should reach the Piaseczno Wiadukt stop, integrated with the Piaseczno PKP station. Then you can build a short branch along ul. Dworcowa and organize a transfer point in front of the Piaseczno Railway Station, creating the main Piaseczno transfer junction integrating SKM, Piaseczyńska Narrow-Gauge Railway, and a two-system tram.

3. Extending the line of the Piaseczyńska Narrow-Gauge Railway, based on the construction of a third track along the route of a double-system tram running through Piaseczno, up to the second important Puławska/Okulickie interchange. In this way, a high frequency of running in the city center would be achieved and direct access from Gołków, Złotokłos, Tarczyn, and Grójec would be ensured. Similar solutions are used in some German agglomeration transport systems. The center of Piaseczno may be entered by a diesel railbus (such as in Zwickau) or a hybrid vehicle, adapted to both diesel and electric traction (such as in Chemnitz, Kassel [10] or Nordhausen [7]).

4. Construction of the third track or the conversion of the narrow track to the normal one on the section Piaseczno - Tarczyn - Grójec in order to introduce standard-gauge rolling stock. It is an optional solution in the longer term, because the passenger flows in this direction will not reach the size of the flows on the Piaseczno-Warsaw route, and the frequency of trains can be assumed at the level of 20-30 minutes during rush hours (based on the analysis of the current bus timetables [35 ], [42]). The construction of the third track in the further section, i.e. on the line No. 8 to Warsaw, seems economically and functionally unjustified.

5. Expansion of the tram network in the city and commune of Piaseczno by building further branches of the basic route of the double-system tram. Consider, for example, the second line running through the city along the north-south axis and the transverse line in Jana Pawła II Street and the line to Józefosław. Finally, also a tram route along ul. Puławska to the Wyścigi loop if they justify future passenger flows.

6. Reconstruction of the Warsaw junction by building a new cross-city line along the northsouth axis along Jana Pawła II Avenue in Warsaw, with the new, "tower" Central Railway Station at the intersection of both cross-city lines. The new two- or four-track railway line would start at the new Warszawa Służewiec station and would be routed through a tunnel to Warszawa Gdańska or Warszawa Wileńska stations. This would make it possible to route trains on the line No. 8, as well as two-system vehicles serving the center of Piaseczno in completely new routes, directly to the very center of Warsaw, bypassing the Warszawa Zachodnia station. It is a promising direction for the development of the transport service system for the entire southern band of the Warsaw agglomeration.

The proposed directions for the development of the transport system take into account not only the general trends in the restoration and modernization of railway lines throughout Western Europe. First of all, they use the potential of the existing, unused infrastructure and the possibility of introducing modern, unconventional solutions in rail transport, including intermediate solutions between city trams and rail [11], [12], [28], [29]. 


\section{Summary}

The main element of the concept presented in the article is the line of the double-system tram from Warsaw to Piaseczno, using the extensive railway line No. 8. Of course, such a tram bypasses Puławska Street. First of all, however, it is to serve Piaseczno, and not the western periphery of the Warsaw-Ursynów district. Secondly: the solution proposed in the article is easy to stage because there is always a possibility of building a tram line in the corridor of Puławska Street and its integration in Piaseczno with the already built line. In the presented concept, no section of the newly created railroad will be lost. Thirdly: a two-system tram will provide access to Warsaw-Mokotów in a time shorter by about 20-30\% compared to the tram on Puławska Street [1], [36], [42]. Fourthly, the introduction of trams to the railway line No. 8 (and so planned to be expanded to four tracks) will replace the construction of a tram route parallel to it, almost $10 \mathrm{~km}$ long.

The further development of the system is based on the assumption of the integration of various means of rail transport. In particular, the adaptation to regular passenger transport was planned for the railway lines that are not used for this purpose today: standard-gauge railway no. 937 (Siding to EC "Siekierki") and the Piaseczyńska Narrow-Gauge Railway.

In both cases, a gradual adaptation of the infrastructure and development of connections was proposed, starting with the introduction of a light diesel rolling stock and the organization of convenient transfers to a double-system tram and SKM trains. Ultimately, the lines will create a coherent system of integrated rail and tram transport.

The proposed model of rail transport in the southern band of the Warsaw agglomeration may be the starting model for servicing other parts of the Warsaw Metropolitan Area and other urban regions. The presented concept will require further detailed analyzes and pre-design works and, first of all, inclusion in part or in whole into strategic documents of local governments and municipalities of Piaseczno, the capital city of Warsaw and the Mazowieckie Voivodeship.

\section{Source materials}

[1] Analiza funkcjonalno-ruchowa trasy tramwajowej do Piaseczna, Trans-Eko, Warszawa, 2006

[2] Analiza techniczna trasy tramwajowej do Piaseczna, Trans-Eko, Warszawa, 2006

[3] Bagieński W., Z historii Grójeckiej Kolei Wąskotorowej 1898-1998. Rocznik Mazowiecki, Warszawa, 2000, nr 12, s. 227-236

[4] Basiewicz T. i inni., Warunki wykorzystania infrastruktury kolejowej przez pojazdy kolejowo-tramwajowe. Zintegrowany system miejskiego transportu szynowego (materiały konferencyjne), 2003, s. 19-24

[5] Czyczuła W., Raczyński J., Pojazd dwusystemowy jako środek transportu regionalnego. Technika Transportu Szynowego, 2000, nr 11, s. 37-42

[6] Giza A., Uryga B., Analiza możliwości przejazdy 24 par pociągów w godzinie szczytu przez warszawską podmiejską linię średnicową, PKP PLK, Warszawa, 2018

[7] Harassek A., Dwusystemowy tramwaj w Nordhausen. Technika Transportu Szynowego 2004, nr 6, s. 54-55

[8] Kraśkiewicz C., Oleksiewicz W., Tramwaj dwusystemowy - moda, czy trend rozwojowy aglomeracyjnego transportu szynowego? Logistyka, 2015, nr 4, s. 42474254

[9] Kraśkiewicz C., Oleksiewicz W., Tramwaj dwusystemowy w Karlsruhe. Logistyka, 2015, nr 4, s. 4255-4261

[10] Kraśkiewicz C., Oleksiewicz W., Tramwaje dwusystemowe w wybranych miastach niemieckich. Technika Transportu Szynowego 2016, nr 12, s. 452--458 
[11] Kruszyna M., Program tramwajowy jako bodziec do wprowadzenia mniej konwencjonalnych rozwiązań z zakresu miejskiej infrastruktury szynowej, Przegląd Komunikacyjny 2017, nr 04/2017, s. 8-12

[12] Makuch J., Propozycja niekonwencjonalnego sposobu prowadzenia nowej linii tramwajowej, Przegląd Komunikacyjny 2015, nr 09/2015, s. 58-62

[13] Molecki B., Badania symulacyjne zintegrowanego transportu szynowego, Zintegrowany system miejskiego transportu szynowego (materiały konferencyjne), 2003, s. 159-163

[14] Plan zagospodarowania przestrzennego województwa mazowieckiego, Sejmik Województwa Mazowieckiego, Warszawa, 2018

[15] Plan zrównoważonego rozwoju transportu zbiorowego dla m.st. Warszawy z uwzględnieniem publicznego transportu zbiorowego organizowanego na podstawie porozumień z gminami sąsiadującymi, Urząd m. st. Warszawy, Warszawa, 2014

[16] Pokropiński B., Kolej grójecka, Wydawnictwa Komunikacji i Łączności, Warszawa, 2002

[17] Program rozwoju i modernizacji technologicznej transportu szynowego w województwie mazowieckim, Mazowieckie Biuro Planowania Regionalnego w Warszawie, Warszawa, 2015

[18] Przebudowa urządzeń sterowania ruchem kolejowym na stacji Warszawa Zachodnia. Projekt budowlany, Torprojekt, Warszawa, 2019

[19] Studium Planu Zagospodarowania Przestrzennego Obszaru Metropolitalnego Warszawy, Mazowieckie Biuro Planowania Regionalnego w Warszawie, Warszawa, 2011

[20] Studium rozwoju i modernizacji technologicznej transportu szynowego na Mazowszu w kontekście polityki transportowej Województwa Mazowieckiego, Mazowieckie Biuro Planowania Regionalnego w Warszawie, Warszawa, 2009

[21] Studium układu komunikacyjnego Gminy Piaseczno, Arup, Warszawa, 2008

[22] Studium uwarunkowań i kierunków zagospodarowania przestrzennego m.st. Warszawy (z późniejszymi zmianami), Rada m.st. Warszawy, Warszawa, 2018

[23] Studium uwarunkowań i kierunków zagospodarowania przestrzennego miasta i gminy Piaseczno, Rada Miejska w Piasecznie, Piaseczno, 2009

[24] Studium uwarunkowań i kierunków zagospodarowania przestrzennego miasta i gminy Piaseczno, Rada Miejska w Piasecznie, Piaseczno, 2014

[25] Warszawskie Badanie Ruchu 2015 wraz z opracowaniem modelu ruchu, opracowanie wykonane przez konsorcjum w składzie: PBS Sp. z o.o. (lider), Politechnika Krakowska i Politechnika Warszawska, na zamówienie m.st. Warszawy, Warszawa, 2016

[26] Wasiak A., Wodzicki R., Studium wykonalności systemu transportowego w powiecie piaseczyńskim ze szczególnym uwzględnieniem pasażerskiej komunikacji kolejowej dla linii kolejowej Warszawa - Radom oraz bocznicy kolejowej Elektrociepłowni Siekierki oraz autobusowej komunikacji poprzecznej, Studio ELDAR, Warszawa - Piaseczno, 2009

[27] Wieczorek J., Problemy eksploatacyjno-ruchowe związane z wprowadzeniem pojazdów dwusystemowych na sieć PKP. Technika Transportu Szynowego, 2000, nr 1-2, s. 44-46

[28] Wild P., Wrocławska kolej metropolitalna, Przegląd Komunikacyjny 2012, nr 10/2012, s. $28-33$

[29] Wontorski P., Koncepcja zintegrowanego systemu transportu szynowego w Radomiu z tramwajami dwusystemowymi. Przegląd Komunikacyjny 2018, nr 07/2018, s. 23-31

[30] http://www.kolejka-piaseczno.pl/, data dostępu: 29.09.2019

[31] http://www.openstreetmap.org/, data dostępu: 29.09.2019

[32] http://www.siskom.waw.pl/kp-tramwaje.htm, data dostępu: 29.09.2019 
[33] https://bdl.stat.gov.pl/BDL/start, data dostępu: 29.09.2019

[34] https://piasecznonews.pl/czy-metro-dojedzie-do-piaseczna/, data dostępu: 29.09.2019

[35] https://pkspolonus.pl/linie-lokalne/tabliczki-przystankowe/Piaseczno, data dostępu: 29.09.2019

[36] https://rozklad-pkp.pl/, data dostępu: 29.09.2019

[37] https://semaforek.kolej.org.pl/wiki/index.php?title=Warszawa_Ok\%C4\%99cie, data dostępu: 29.09.2019

[38] https://semaforek.kolej.org.pl/wiki/index.php?title=Piaseczno, data dostępu: 29.09.2019

[39] https://www.gazetaprawna.pl/artykuly/1421064,warszawa-pkp-linia-srednicowaprzebudowa-beda-utrudnienia.html, data dostępu: 29.09.2019

[40] https://www.transport-publiczny.pl/mobile/warszawa-gdzie-rozwijac-metro-i-tramwaje-jest-plan-systemu-transportowego-60813.html, data dostępu: 29.09.2019

[41] https://www.transport-publiczny.pl/wiadomosci/skm-z-piaseczna-na-linie-obwodowa-idw-gdanski-najwczesniej-po-2023-r-61245.html, data dostępu: 29.09.2019

[42] https://www.ztm.waw.pl/, data dostępu: 29.09.2019 